\title{
The effect of the KWL strategy on Vietnamese fifth-grade students' reading comprehension achievement at Vstar school
}

\author{
Le Thi Thao $\mathrm{Vy}^{1 *}$, Nguyen Thi Thanh $\mathrm{Ha}^{2}$ \\ ${ }^{1}$ English Language Teaching, Vietnam \\ ${ }^{2}$ Van Hien University, Vietnam \\ *Corresponding author: lethithaovy611@gmail.com
}

\begin{abstract}
ARTICLE INFO
ABSTRACT

DOI: $10.46223 / \mathrm{HCMCOUJS}$. soci.en.10.1.547.2020

Received: June $15^{\text {th }}, 2020$

Revised: June $23^{\text {rd }}, 2020$

Accepted: June $24^{\text {th }}, 2020$

Keywords:

reading comprehension, the KWL strategy

The paper aimed at examining how the use of the Know - Want to Know - Learned (KWL) strategy affected fifth-graders' reading comprehension achievement at Vstar School in Ho Chi Minh City. To achieve the aim of the study, the researcher employed a quantitative approach with a two-group quasi-experimental pretestposttest design. Data was collected via a questionnaire, a pretest, and a posttest conducted on 50 students of two fifth-grade classes $(\mathrm{N}=25$ for each class) which were conveniently chosen from 270 fifthgraders at Vstar School. The research results indicated statistically significant differences in reading comprehension achievement of the experimental class between the pretest and the posttest with better results found in the posttest. Additionally, there were also statistically significant differences between the control class and the experimental class after the application of the KWL strategy. Based on the findings, some recommendations were suggested to teachers of English, students learning English as a foreign language (EFL), and researchers having an interest in the topic.
\end{abstract}

\section{Introduction}

In recent decades, Vietnam has made great efforts to improve Vietnamese people's English proficiency. It can be seen through the National Project for "Teaching and Learning Foreign Language in the National Formal Educational System in the period of 2008 - 2020" (Hoang, 2010) and changes in language education policy at the primary level (T. M. H. Nguyen \& Q. T. Nguyen, 2007). Great attempts have been also made to enhance the quality of English teaching and learning in Vietnam, especially reading skills (Hoang, 2010).

Despite the great efforts devoted to improving the quality of reading instruction, Vietnamese learners still encounter many difficulties in comprehending English texts (Ho, 2016; Tran \& Duong, 2018). Inadequate vocabulary, lack of background knowledge, and lack of motivation to read are believed to be factors that can affect learners' reading comprehension (Ho, 2016; Nguyen, 2018; Tran \& Duong, 2018).

Research suggests that strategy instruction can result in an enhancement in learners' reading comprehension (Duke \& Pearson, 2002). One of the reading strategies that is believed to have a positive impact on learners' reading comprehension is the KWL strategy. The KWL strategy has proved its beneficial effect on the reading comprehension of learners from many levels in many countries (Hamdan, 2014; Riswanto, Risnawati, \& Lismayanti, 2014; Setiawan \& 
Suhartono, 2014; Tran, 2016; Utami, Bindarti, \& Suharjito, 2014).

However, the findings of some of the previous studies (Setiawan \& Suhartono, 2014; Riswanto \& Lismayanti, 2014) seem less convincing due to some limitations in research designs and data analysis. Research on the instruction of the KWL strategy in the Vietnamese context is still limited. Finally, few empirical research on the topic has been carried out on primary school students. Given the aforementioned reasons, the study sought to investigate the effect of the KWL strategy on reading comprehension achievement of Vietnamese fifth-grade students at VStar School in Ho Chi Minh City.

\section{Literature review}

\subsection{Reading comprehension}

Reading comprehension is a complex construct. Comprehension is composed of different levels. At a fundamental level, word recognition and word grouping occur (Wagner \& Bond, 1966). At a higher level, comprehension asks for readers' ability to identify the connections among sentences, then among paragraphs, and finally, they can find out the meaning of the whole text. Similarly, according to Amaliani (2017), reading comprehension is a complicated cognitive psycholinguistic process in which readers' comprehension of the text is modified simultaneously based on their background knowledge when they progress through the text.

Besides background knowledge, reading comprehension also involves many other elements including learner's vocabulary, metacognitive strategies, reading strategies (Koda, 2007); learner's attitudes (McKenna, Kear, \& Ellsworth, 1995); the amount of exposure to the target language (Chesterfield, Hayes-Latimer, Chesterfield, \& Chavez, 1983; Ellis, 2002). Among all the elements, learner's background knowledge or schemata and metacognitive strategies are believed to be the most crucial in comprehending a text (Anderson, 2003; Çakıc1, 2017). Therefore, schemata and metacognition are going to be investigated thoroughly in the following parts.

\subsection{Schemata and reading comprehension}

Schema theory is based on Goodman's (1967) psycholinguistic model with the fundamental idea that comprehending a written text incorporates an interactive process between the text and the readers' previous knowledge. According to Rummelhart (1980), schema serves as the skeleton where the readers can interpret the reading text in various ways. An increasing mass of research has emphasized the role of background knowledge or schemata in the improvement of learners' reading comprehension in an EFL context (Al-Jahwari \& Al-Humaidi, 2015; Khanam, Zahid, \& Mondol, 2014). According to Khanam et al. (2014), in the process of reading, learners may encounter some information gaps which are assumed to be filled up with assumptions shared by the writer and the reader. They also suggest that the more assumptions, which are named as schemata, both the writer and the reader share, the better the reader can comprehend the text.

\subsection{Metacognition and reading comprehension}

Besides schemata, another important variable for comprehending reading text that is worth mentioning is the metacognitive strategy. The notion metacognition which was created by Flavell (1976) refers to knowledge of cognitive processes to control and regulate comprehension with particular goals. In addition, metacognition entails cognitive awareness of planning, controlling, repairing, revising, summarizing, and assessing.

A great number of studies on metacognition have been carried out concerning reading comprehension (Carrell, Gajdusek, \& Wise, 1998; Devine, 1993). Research points out that the application of metacognitive strategies is one of the factors contributing to the differences between 
effective and ineffective readers. In the 1980s, it was revealed that metacognition plays an essential part in learners' reading abilities (Schmitt, 2013).

However, it has been widely agreed and proved by many researchers that strategies themselves may not be useful or useless (Cohen, 2003; Grabe, 2004). Instead, readers' ability to take control of their comprehension or metacognitive awareness is one of the decisive factors to enhance comprehension effectiveness.

Based on what discussed above, a strong connection among schemata, metacognition, and reading comprehension can be seen. Background knowledge or schemata and metacognitive strategies are believed to be the most essential elements that are required to construct meaning from a given text during an interactive process of reading (Anderson, 2003; Çak1c1, 2017). Therefore, it is the teachers' responsibility to facilitate learners' use of strategies that can recall their background knowledge and enhance their metacognition, thus resulting in reading comprehension improvement. To do this, reading strategy instruction is believed to be an effective measure (Duke \& Pearson, 2002). Among various strategies of teaching reading, it is believed that the KWL strategy is the one that can meet the requirement of activating learners' schemata and improving their metacognition (Erliana, 2017).

\subsection{The KWL strategy}

The KWL strategy is a three-stage reading strategy developed by Ogle (1986). Each letter K, W, L stands for each stage: brainstorming what I Know about the topic, identifying what I Want to know about the topic, and rethinking what I have Learned from the reading text.

The KWL strategy is believed to benefit both students and teachers in reading classes. In particular, the KWL strategy can activate students' prior knowledge, set a purpose for reading, help them keep track of their reading, enable them to self-assess their learning and develop ideas out of the text (Conner, 2003, as cited in El-Koumy, 2004). Shepard (2000) also adds that the use of the chart helps students stay concentrated and engaged while reading and make them feel accomplished after filling what they have learned. Besides, the KWL model not only helps learners develop an active reading of expository material but also encourages teachers' responsiveness to students' prior knowledge while reading (Ogle, 1986). Ogle (1986) developed the KWL strategy with the idea that teachers should honor students' prior knowledge brought to reading situations.

\section{achievement \\ 2.5. Research on the impact of the KWL strategy on learners' reading comprehension}

A mass of research has proved the beneficial effect of the KWL strategy on reading comprehension of learners from many levels in many countries (Hamdan, 2014; Riswanto \& Lismayanti, 2014; Setiawan \& Suhartono, 2014; Tran, 2016; Utami et al., 2014). Many studies have been conducted on junior high school students. In particular, Setiawan and Suhartono (2014) and Riswanto and Lismayanti (2014) revealed the improvement in reading comprehension of Indonesian students, seventh graders, and eighth-graders, respectively, with the application of the KWL strategy. However, while Setiawan and Suhartono (2014) did not clearly state the length of time between the pretest and posttest, the amount of time the treatment was applied, and how the tests were constructed, Riswanto and Lismayanti (2014) did not show how differently the experimental group and the control group were taught.

Besides junior high school students, high school students are also the participants of many studies on the topic (Hamdan, 2014; Utami et al., 2014). Utami et al. (2014) were applying the posttest only design in the study on Indonesian high school students, eleventh-grade students, also 
stated the enhancement in the students' reading comprehension with the use of the KWL strategy. The research by Hamdan (2014) with pretest-posttest design yielded the same result in which 50 Jordanian tenth-grade male students showed improved reading comprehension achievement with the use of the KWL strategy. However, while the sample size and the length of time between the pretest and posttest were mentioned in Hamdan's (2014) study, they were not clearly stated in the research of Utami et al. (2014).

As can be seen, the results of some of the previous studies (Riswanto \& Lismayanti, 2014; Setiawan \& Suhartono, 2014) seem less convincing because of some flaws in the methodology discussed above. Additionally, little empirical research on the topic has been conducted in Vietnam. One noticeable study on the influence of the KWL technique on students' reading comprehension was conducted by Tran (2016). Finally, research on the topic carried out on primary school students is very limited. To the best of my knowledge, only one study on the topic was undertaken on the fifth-grade students (Burns, 1994, as cited in El-Koumy, 2004). Given the reasons above, the present study sought to examine the effect of the KWL strategy on reading comprehension achievement of fifth-graders at VStar School in Ho Chi Minh City, Vietnam. In this study, "achievement" refers to the participants' reading comprehension scores.

The research question that guided the paper is:

To what extent does the KWL strategy affect the reading comprehension achievement of Vietnamese fifth-grade students at VStar School?

\section{Methodology}

\subsection{Participants}

The research consisted of 50 elementary-level students of two fifth-grade classes $(\mathrm{N}=25$ for each class) which were conveniently chosen from 270 fifth-graders at Vstar School. The two intact classes were then randomly chosen to be the experimental class $(\mathrm{N}=25)$ and control class $(\mathrm{N}=25)$ by a random number generator. All the students were ten-year-old native speakers of Vietnamese and had never lived abroad.

\subsection{Instruments}

\section{Pretest and posttest}

A pretest and a posttest were used in this study to investigate the impact of KWL strategy on the participants' reading comprehension achievement. The two tests were taken from Cambridge Key English Test (KET) 7 (Cambridge ESOL, 2014) published by Cambridge University Press. The KET reading test lasts for 40 minutes and includes five parts with 35 questions in total. It focuses on assessing learners' ability to understand the meaning of different levels of written English, from words, phrases, sentences to paragraphs, and texts (Association of Language Testers in Europe, 2007). The pretest covered the content that the participants had learned in previous years at VStar while the posttest included the ideas, words, and skills they learned during the 10-week time of the experiment.

Cronbach's Alpha was calculated to estimate the internal consistency of the pretest and posttest in the main study. The ideal Cronbach alpha coefficient of a scale should be higher than .7 (DeVellis, 2003, as cited in Pallant, 2011). The Cronbach's alpha coefficient of the pretest was .823 and the value of the posttest was .828. In other words, the pretest and posttest were reliable.

\subsection{Design and procedures}

The study employed a quantitative approach with a two-group quasi-experimental pretest- 
posttest design. After the two intact classes had been chosen to participate in the study, they were randomly chosen to be the control class and experimental class. The questionnaire was conducted one week before the pretest to control some extraneous variables that could influence the study outcomes. As the results of the normality and homogeneity tests of the questionnaire data for the control class and experimental class indicated that the assumptions of parametric tests were not met (sig. values were smaller than .05), Mann-Whitney $U$ tests were conducted on the questionnaire data to find out whether there were statistically significant differences between the control class and the experimental class in terms of their amount of exposure to English, attitudes towards English, amount of exposure to English out of classroom setting and familiarity with some popular topics. The results of the Mann-Whitney $U$ tests showed no statistically significant difference between the control class and the experimental class with significance levels of the tests ranging from .068 to 1.0. Then, the pretest was conducted on both the experimental class and the control class in the second week. The participants took the test in their class with the close supervision of the researcher. At the beginning of the third week, the KWL strategy started to be applied to teaching reading comprehension for the experimental class while the control class was still instructed with the regular teaching method. Both classes were taught by the researcher. The experimental class was exposed to the KWL technique for 70 minutes per week. The treatment lasted for ten weeks. The control class was instructed with the regular teaching method. The researcher had the two classes learn the same knowledge and skills, use the same reading texts, and do the same tasks during the experiment, except for the treatment. The posttest was conducted on two classes after the treatment. Then, the results of the pretest and posttest were assessed if they could meet the assumptions for parametric tests. The results of the normality and homogeneity tests of the pretest scores and posttest scores for the control class and experimental class indicated that the assumptions of parametric tests were met. In particular, regarding the normality tests, the sig. values of the pretest scores for the control class and the experimental class were higher than .05 , being .060 and .095 respectively, and .070 and .077 respectively for the posttest scores. In terms of the tests of homogeneity of the pretest and the posttest, the sig. values based on the mean were higher than .05 , being .271 and .059 respectively. After that, the test scores were analyzed with t-tests. To see the magnitude of the differences between the control class and experimental class, effect size or eta squared was calculated using the output of the independent-samples t-tests and paired-samples t-tests. In terms of independent-samples t-test, the procedure for calculating eta squared is presented below:

$$
\text { Eta squared }=\frac{\mathrm{t}^{2}}{\mathrm{t}^{2}+(\mathrm{N} 1+\mathrm{N} 2-2)}
$$

Regarding paired-samples t-test, the procedure for calculating eta squared is shown below:

$$
\text { Eta squared }=\frac{\mathrm{t}^{2}}{\mathrm{t}^{2}+(\mathrm{N}-1)}
$$

The result might be interpreted by following the guidelines by Cohen (1988):

$.01=$ small effect

$.06=$ moderate effect

$.14=$ large effect 


\section{Research results}

\subsection{Comparison between the control class and experimental class' pretest scores}

Table 1

Group Statistics of the Control Class and Experimental Class' Pretest Scores

\begin{tabular}{llrrrr}
\hline & Class & N & & Mean & \multicolumn{2}{c}{ Std. Deviation Std. Error Mean } \\
\hline \multirow{2}{*}{ Pretest Scores } & Experimental class & 25 & 16.32 & 3.579 & .716 \\
& Control class & 25 & 16.76 & 3.179 & .636 \\
\cline { 3 - 6 }
\end{tabular}

Source: Data analysis result of the research

Table 2

Independent Samples T-Test of the Control Class and Experimental Class' Pretest Scores

\begin{tabular}{|c|c|c|c|c|c|c|c|c|c|c|}
\hline & & \multicolumn{2}{|c|}{$\begin{array}{c}\text { Levene's Test for } \\
\text { Equality of Variances }\end{array}$} & \multicolumn{7}{|c|}{ t-test for Equality of Means } \\
\hline & & \multirow[t]{2}{*}{ F } & \multirow[t]{2}{*}{ Sig. } & \multirow[t]{2}{*}{$\mathrm{t}$} & \multirow[t]{2}{*}{$\mathrm{df}$} & \multirow[t]{2}{*}{$\begin{array}{l}\text { Sig. (2- } \\
\text { tailed) }\end{array}$} & \multirow[t]{2}{*}{$\begin{array}{c}\text { Mean } \\
\text { Difference }\end{array}$} & \multirow[t]{2}{*}{$\begin{array}{l}\text { Std. Error } \\
\text { Difference }\end{array}$} & \multicolumn{2}{|c|}{$\begin{array}{c}95 \% \text { Confidence } \\
\text { Interval of the } \\
\text { Difference }\end{array}$} \\
\hline & & & & & & & & & Lower & Upper \\
\hline Pretest & $\begin{array}{l}\text { Equal variances } \\
\text { assumed }\end{array}$ & 1.242 & .271 & -.460 & 48 & .648 & -.440 & .957 & -2.365 & 1.485 \\
\hline Scores & $\begin{array}{l}\text { Equal variances } \\
\text { not assumed }\end{array}$ & & & -.460 & 47.341 & .648 & -.440 & .957 & -2.366 & 1.486 \\
\hline
\end{tabular}

Source: Data analysis result of the research

An independent-samples t-test was conducted to compare the reading comprehension pretest scores for the control class and experimental class. As can be seen from Table 2, Levene's test indicated equal variances $(F=1.242, p=.271>.05)$, so the results of the t-test in the Equal variances assumed row were used. Based on Table 1 and Table 2, there was no statistically significant difference in the scores for the control class $(M=16.76, S D=3.179)$ and experimental class $(M=16.32, S D=3.579 ; t(48)=-.460, p=.648$, two-tailed, and $p>.05)$. It can be concluded that there was no statistically significant difference between the control class and experimental class before the application of the KWL strategy.

\subsection{Comparison between the control class' pretest and posttest scores}

\section{Table 3}

Paired Samples Statistics of the Control Class' Pretest and Posttest Scores

\begin{tabular}{cccccc}
\hline & Mean & N & Std. Deviation & Std. Error Mean \\
\hline \multirow{2}{*}{ Pair 1 } & Pretest Scores & 16.76 & 25 & 3.179 & .636 \\
& Posttest scores & 18.76 & 25 & 4.594 & .919 \\
\hline
\end{tabular}




\section{Table 4}

Paired Samples T-Test of the Control Class' Pretest and Posttest Scores

\begin{tabular}{|c|c|c|c|c|c|c|c|c|c|}
\hline & & \multicolumn{5}{|c|}{ Paired Differences } & \multirow{4}{*}{$\mathrm{t}$} & \multirow{4}{*}{ df } & \multirow{4}{*}{$\begin{array}{l}\text { Sig. (2- } \\
\text { tailed) }\end{array}$} \\
\hline & & \multirow{3}{*}{ Mean } & \multirow{3}{*}{$\begin{array}{c}\text { Std. } \\
\text { Deviation }\end{array}$} & \multirow{3}{*}{$\begin{array}{l}\text { Std. Error } \\
\text { Mean }\end{array}$} & \multirow{2}{*}{\multicolumn{2}{|c|}{$\begin{array}{l}95 \% \text { Confidence } \\
\text { Interval of the } \\
\text { Difference }\end{array}$}} & & & \\
\hline & & & & & & & & & \\
\hline & & & & & Lower & Upper & & & \\
\hline Pair 1 & $\begin{array}{l}\text { Pretest Scores - } \\
\text { Posttest scores }\end{array}$ & -2.000 & 2.754 & .551 & -3.137 & -.863 & -3.631 & 24 & .001 \\
\hline
\end{tabular}

Source: Data analysis result of the research

A paired-samples t-test was conducted to evaluate the impact of the regular teaching method on reading comprehension scores of students from the control class. Based on Table 3 and Table 4, there was a statistically significant increase in reading comprehension scores from the pretest $(M=16.76, S D=3.179)$ to the posttest $(M=18.76, S D=4.594), t(24)=-3.631, p=.001$ (two-tailed). The eta squared statistic (0.35) indicated a large effect size. Therefore, it could be concluded that there was a large effect, with a substantial difference in the reading comprehension scores achieved by the participants in the control class before and after the regular teaching method.

\subsection{Comparison between the experimental class'pretest and posttest scores}

\section{Table 5}

Paired Samples Statistics of the Experimental Class' Pretest and Posttest Scores

\begin{tabular}{llllcc}
\hline & & Mean & N & \multicolumn{2}{c}{ Std. Deviation Std. Error Mean } \\
\hline \multirow{2}{*}{ Pair 1 } & Pretest Scores & 16.32 & 25 & 3.579 & .716 \\
& Posttest scores & 21.16 & 25 & 3.613 & .723 \\
\hline
\end{tabular}

Source: Data analysis result of the research

\section{Table 6}

Paired Samples T-Test of the Experimental Class' Pretest and Posttest Scores

\begin{tabular}{|c|c|c|c|c|c|c|c|c|c|}
\hline & & \multicolumn{5}{|c|}{ Paired Differences } & \multirow{4}{*}{$\mathrm{t}$} & \multirow{4}{*}{$\mathrm{df}$} & \multirow{4}{*}{$\begin{array}{l}\text { Sig. (2- } \\
\text { tailed) }\end{array}$} \\
\hline & & \multirow{3}{*}{ Mean } & \multirow{3}{*}{$\begin{array}{c}\text { Std. } \\
\text { Deviation }\end{array}$} & \multirow{3}{*}{$\begin{array}{c}\text { Std. Error } \\
\text { Mean }\end{array}$} & \multicolumn{2}{|c|}{$95 \%$ Confidence } & & & \\
\hline & & & & & $\begin{array}{r}\text { Inter } \\
\text { Dif }\end{array}$ & $\begin{array}{l}\text { of the } \\
\text { nce }\end{array}$ & & & \\
\hline & & & & & Lower & Upper & & & \\
\hline Pair 1 & $\begin{array}{l}\text { Pretest Scores - } \\
\text { Posttest scores }\end{array}$ & -4.840 & 2.173 & .435 & -5.737 & -3.943 & -11.135 & 24 & .000 \\
\hline
\end{tabular}


Another paired-samples t-test was carried out to assess the effect of the KWL strategy on reading comprehension scores of the experimental class. As can be seen from Table 5 and Table 6 , there was a statistically significant increase in reading comprehension scores from the pretest $(M=16.32, S D=3.579)$ to the posttest $(M=21.16, S D=3.613), t(24)=-11.135, p=.000$ (twotailed). The eta squared statistic (0.83) indicated a very large effect size. In short, it could be concluded that there was a very large effect, with a substantial difference in the reading comprehension scores obtained by the students in the experimental class before and after the intervention of the KWL strategy.

\subsection{Comparison between the control class and experimental class' posttest scores}

\section{Table 7}

\section{Group Statistics of the Control Class and Experimental Class' Posttest Scores}

\begin{tabular}{cccccc}
\hline \multirow{2}{*}{ Class } & $\mathrm{N}$ & Mean & \multicolumn{2}{c}{ Std. Deviation Std. Error Mean } \\
\hline \multirow{2}{*}{ Posttest scores } & Experimental class & 25 & 21.16 & 3.613 & .723 \\
& Control class & 25 & 18.76 & 4.594 & .919 \\
\hline
\end{tabular}

Source: Data analysis result of the research

Table 8

Independent Samples T-Test of the Control Class and Experimental Class' Posttest Scores

\begin{tabular}{|c|c|c|c|c|c|c|c|c|c|c|}
\hline & & $\begin{array}{r}\text { Leven } \\
\text { Equality }\end{array}$ & $\begin{array}{l}\text { est fo } \\
\text { Jarian }\end{array}$ & \multicolumn{7}{|c|}{ t-test for Equality of Means } \\
\hline & & \multirow{3}{*}{ F } & \multirow{3}{*}{ Sig. } & \multirow{3}{*}{$\mathrm{t}$} & \multirow{3}{*}{ df } & \multirow{3}{*}{$\begin{array}{l}\text { Sig. (2- } \\
\text { tailed) }\end{array}$} & \multirow{3}{*}{$\begin{array}{c}\text { Mean } \\
\text { Difference }\end{array}$} & \multirow{3}{*}{$\begin{array}{l}\text { Std. Error } \\
\text { Difference }\end{array}$} & \multirow{2}{*}{\multicolumn{2}{|c|}{$\begin{array}{l}95 \% \text { Confidence } \\
\text { Interval of the } \\
\text { Difference }\end{array}$}} \\
\hline & & & & & & & & & & \\
\hline & & & & & & & & & Lower & Upper \\
\hline \multirow{2}{*}{$\begin{array}{l}\text { Posttest } \\
\text { scores }\end{array}$} & $\begin{array}{c}\text { Equal variances } \\
\text { assumed }\end{array}$ & 3.753 & .059 & 2.053 & 48 & .046 & 2.400 & 1.169 & .050 & 4.750 \\
\hline & $\begin{array}{c}\text { Equal variances } \\
\text { not assumed }\end{array}$ & & & 2.053 & 45.475 & .046 & 2.400 & 1.169 & .046 & 4.754 \\
\hline
\end{tabular}

Source: Data analysis result of the research

The results of the independent-samples t-test of the posttest scores can be found in Table 7 and Table 8. As can be seen, the mean scores of both classes increased. In particular, the mean score of the control class went from 16.76 in the pretest to 18.76 in the posttest and the experimental class' mean score improved from 16.32 in the pretest to 21.16 in the posttest. Additionally, Levene's test indicated equal variances $(F=3.753, p=.059>.05)$, so the results of the t-test in the Equal variances assumed row were used. There was a statistically significant difference in scores for the control class $(M=18.76, S D=4.594)$ and experimental class $(M=$ 21.16, $S D=3.613 ; t(48)=2.053, p=.046$, two-tailed, and $p<0.05)$. The magnitude of the differences in the means (mean difference $=2.4,95 \%$ CI [.050 to 4.750] was large (eta squared $=$ 
.08). In short, there was a statistically significant difference in the reading comprehension scores between the control class and the experimental class after the application of the KWL strategy. It can be concluded that the KWL strategy had a significant impact on the students' reading comprehension achievement.

\section{Discussion}

The current study indicated the effectiveness of the KWL strategy in enhancing the students' reading comprehension achievement. The results of the study also support previous research (Hamdan, 2014; Riswanto \& Lismayanti, 2014; Setiawan \& Suhartono, 2014; Tran, 2016; Utami et al., 2014), despite different research contexts, designs, methodology, or levels of participants.

In the current study, the KWL strategy was applied to activate the students' background knowledge and improve their metacognition as well as simultaneously trained the participants to gradually employ the strategy during the reading process. The impact of each step of the strategy on learners' reading comprehension can be interpreted as follows. First, the effect of the K step on the students' reading comprehension achievement can be explained in the light of the Schema theory (Goodman, 1967) in which learners' prior knowledge or schema is believed to strongly impact how they could comprehend a reading text. The text serves as a direction-giver to the readers to figure out the meaning of the text by using their schemata. Second, the influence of the W step on the learners' reading comprehension achievement could be interpreted in the light of the effect of metacognition on learners' reading comprehension (Flavell, 1976; Schmitt, 2013). In particular, the W step asked for the participants' purpose-setting for reading and self-questioning which are metacognitive strategies to help the students plan their reading process. Finally, the impact of the L step on the learners' reading comprehension results could also be understood in light of the close connection between metacognition and reading comprehension (Schmitt, 2013). To be specific, when the students were asked to note down words and ideas they had learned from the texts, they were required to self-assess and reflect on their learning process.

\section{Conclusions and recommendations}

\subsection{Conclusions}

Given the data analysis discussed above, it can conclude that there was a statistically significant difference in the students' reading comprehension achievement before and after the use of the KWL strategy. The KWL strategy was proved to be effective in improving the students' reading comprehension achievement as it could aid the students in dealing with some difficulties while they were reading a text with the three steps to activate their schemata, set purposes for reading, and reflect on their learning process. In conclusion, the KWL strategy was proved to impose a positive effect on the fifth-grade students' reading comprehension achievement at VStar School in Ho Chi Minh City.

\subsection{Recommendations}

Based on the results of the study, some recommendations are proposed for teachers of English, EFL students and researchers having an interest in the research topic. Concerning teachers of English, they should be aware of the importance of background knowledge and metacognition to design lessons to activate learners' prior knowledge related to learning topics and enhance their metacognitive skills. As for EFL students, they are expected to make use of the KWL strategy as an independent learning strategy during their reading process to achieve better results in reading comprehension. Concerning further research, more studies should be carried out to examine if the 
KWL strategy affects learners' achievement of other skills, such as listening, speaking, and writing or on learners of different English ability levels, for example, intermediate or advanced levels.

\section{References}

Al-Jahwari, Y., \& Al-Humaidi, S. (2015). Prior knowledge in EFL reading comprehension: Omani teachers' perspective \& classroom strategies. International Journal of Applied Linguistics \& English Literature, 4(1), 169-181. doi:10.7575/aiac.ijalel.v.4n.1p.169

Amaliani, P. (2017). The effect of using KWL chart technique on students' reading comprehension of descriptive text (Unpublished master's thesis). Syarif Hidayatullah Jakarta University, Jakarta, Indonesia.

Anderson, N. J. (2003). Teaching reading. In D. Nunan (Ed.), Practical English language teaching (pp. 67-86). New York, NY: McGraw Hill Publishers.

Association of Language Testers in Europe. (2007). Key English test handbook for teachers. $\begin{array}{llll}\text { Retrieved } \quad \text { October 20, from } & \text { 2019, }\end{array}$ http://www.iltea.org/cambridge/KET/ket_handbook2007.pdf

Çakıcı, D. (2017). An overview of metacognitive strategies in reading comprehension skill. The Journal of Academic Social Science Studies, 57, 67-82. doi:10.9761/JASSS7074

Cambridge ESOL. (2014). Cambridge key English test 7. Cambridge, UK: Cambridge University Press.

Carrell, P. L., Gajdusek, L., \& Wise, T. (1998). Metacognition and EFL/ESL reading. Instructional Science, 26(1/2), 97-112. doi:10.1023/A:1003092114195

Chesterfield, R., Hayes-Latimer, K., Chesterfield, K. B., \& Chavez, R. (1983). The influence of teachers and peers on second language acquisition in bilingual preschool programs. TESOL Quarterly, 17(3), 401-419. doi:10.2307/3586255

Cohen, A. D. (2003). The learner's side of foreign language learning: Where do styles, strategies, and tasks meet? International Review of Applied Linguistics in Language Teaching, 41(4), 279-291. doi:10.1515/iral.2003.013

Devine, J. (1993). The role of metacognition in second language reading and writing. In J. Carson \& I. Leki (Eds.), Reading in the composition classroom: Second language perspectives (pp. 105-127). Boston, MA: Heinle and Heinle.

Duke, N. K., \& Pearson, P. D. (2002). Effective practices for developing reading comprehension. In A. E. Farstrup \& S. J. Samuels (Eds.), What research has to say about reading instruction (3rd ed., pp. 205-242). Newark, DE: International Reading Association.

El-Koumy, A. S. (2004). Metacognition and reading comprehension: Current trends in theory and research. $\quad$ Retrieved October 22, 2019, from https://www.academia.edu/3705950/Metacognition_and_Reading

_Comprehension_Current_Trends_in_Theory_and_Research

Ellis, R. (2002). Second language acquisition. Oxford, UK: Oxford University Press.

Erliana, S. (2017). Improving literal and inferential comprehension using know-What to learnlearned (KWL) strategy. LET: Linguistics, Literature and English Teaching Journal, 4(2), 75-93. 
Flavell, J. H. (1976). Metacognitive aspects of problem solving. In L. B. Resnick (Ed.), The nature of intelligence (pp. 231-236). Hillsdale, NJ: Erlbaum.

Goodman, K. S. (1967). Reading: A psycholinguistic guessing game. Journal of the Reading Specialist, 6(4), 126-135. doi:10.1080/19388076709556976

Grabe, W. (2004). Research on teaching reading. Annual Review of Applied Linguistics, 24, 4469. doi:10.1017/S0267190504000030

Hamdan, M. H. (2014). KWL-Plus effectiveness on improving reading comprehension of tenth graders of Jordanian male students. Theory and Practice in Language Studies, 4(11), 22782288. doi:10.4304/tpls.4.11.2278-2288

Ho, C. V. (2016). A Study of reading comprehension problems in English encountered by first year students of faculty of Vietnamese studies at HNUE (Unpublished master's thesis). Hanoi National University of Education, Hanoi.

Hoang, V. V. (2010). The current situation and issues of the teaching of English in Vietnam. 立命 館言語文化研究, 22(1), 7-18.

Khanam, S., Zahid, S. H., \& Mondol, S. (2014). The role of schema for effective EFL reading comprehension. ASA University Review, 8(1), 83-93.

Koda, K. (2007). Reading language learning: Cross-linguistic constraints on second language reading development. Language Learning, 57(1), 1-44. doi:10.1111/0023-8333.101997010-il

McKenna, M. C., Kear, D. J., \& Ellsworth, R. A. (1995). Children's attitudes toward reading: A national survey. Reading Research Quarterly, 30(4), 934-956. doi:10.2307/748205

Nguyen, T. B. T. (2018). Reading strategies used by Vietnamese EFL And ESL university students. VNU Journal of Foreign Studies, 34(2).

Nguyen, T. M. H., \& Nguyen, Q. T. (2007). Teaching English in Vietnam: An overview. Current Issues in Language Planning, 8(2), 162-173. doi:10.2167/cilp106.0

Ogle, D. M. (1986). KWL: A teaching model that develops active reading of expository text. Reading Teacher, 39, 564-570.

Pallant, J. (2011). SPSS survival manual: A step by step guide to data analysis using the SPSS program (4th ed.). Milton Keynes, UK: Open University Press.

Riswanto, R., \& Lismayanti, D. (2014). The effect of using KWL (Know, Want, Learned) strategy on EFL students' reading comprehension achievement. International Journal of Humanities and Social Science, 4(7), 225-233.

Rummelhart, D. E. (1980). Schemata: The building block of cognition. In. R. J. Spiro, B. C. Bruce \& W. F. Brewer (Eds.), Technical issues in reading comprehension, perspective from cognitive psychology, linguistics, artificials intelegence, and education. Hillsdale, NJ: Lowrence Erlbaum Associates Publisher.

Schmitt, N. (2013). An introduction to applied linguistics. New York, NY: Routledge.

Setiawan, A., \& Suhartono, L. (2014). The effectiveness of teaching reading comprehension of descriptive text through KWL strategy. Journal Pendidikan dan Pembelajaran, 3(4), 1-10.

Shepard, L. A. (2000). The role of classroom assessment in teaching and learning (Report No. 517). Los Angeles, CA: University of California. 
Tran, D. T. T. (2016). Trying KWL strategy on teaching reading comprehension to passive students in Vietnam. International Journal of Language and Linguistics, 3(6), 481-492. doi:10.11648/j.ijll.20150306.33

Tran, T. Q., \& Duong, T. M. (2018). The difficulties in esp reading comprehension encountered by English-majored students. VNU Journal of Foreign Studies, 34(2), 151-161. doi:10.25073/2525-2445/vnufs.4253

Utami, D. K. E., Bindarti, W. E., \& Suharjito, B. (2014). The effect of using KWL (know-want to know-learned) strategy on the eleventh grade students' reading comprehension achievement at SMAN 1 Besuki in the 2014/2015 academic year. Retrieved April 5, 2020, from http://repository.unej.ac.id/handle/123456789/63108

Wagner, G. L., \& Bond, E. B. (1966). Teaching the child to read. New York, NY: Macmillan. 